not told what the ultrasound diagnoses in the other 21 was, presumably dilatation of unknown cause. Cystic renal dysplasia can be accurately diagnosed by ultrasound in most cases if the strict criteria of non-communicating cystic spaces, which vary in size and number, is adhered to. It is well recognised that in a few cases it may be difficult to differentiate from hydronephrosis but this is readily achieved either by cyst puncture or radionuclide scintigraphy. It is, however, good practice in all cases to perform a dimercaptosuccinic acid (DMSA) scintigram to confirm total absence of function.

The place of postnatal renal tract ultrasound is quite clear. It should act as a guide to the next examination, although in many cases the specific diagnosis will be apparent. Tudor and Whitaker have recently described a protocol for the detection and management of the dilated fetal urinary tract, which is to be commended. ${ }^{3}$ The ultrasound scans should be performed by individuals skilled in paediatric ultrasound. In a tertiary referral centre one would expect all the scans to be repeated by such an individual before the initiation of treatment or further investigation.

\author{
References \\ 1 Clarke NW, Gough DCS, Cohen SJ. Arch Dis Child 1989;64: \\ 578-80. \\ 2 Arthur RJ, Irving HC, Thomas DFM, Watters JK. Br Med J \\ 1989;298:1419-20. \\ 3 Tudor J, Whitaker RH. Clin Radiol 1989;40:229-30.
}

D R M LiNDSELL Radiology Department, John Radcliffe Hospital, Headington, Oxford $O X 39 D U$

\section{Gall stones in homozygous sickle cell disease}

Sir,

We recently communicated detailed findings on the prevalence and risk factors for gall stones in children with homozygous sickle cell disease. ${ }^{1}$ The study has been repeated to include other sickle genotypes for which there are few data, ${ }^{2}$ and this has enabled comparison of gall stone prevalence between genotypes. It has also enabled us to examine the role of haemolytic rate and mean serum bilirubin concentration, which is the prime determinant of gall stone prevalence in homozygous sickle cell disease. ${ }^{1}$

The children who participated in the Jamaican cohort study of sickle cell disease were aged between 6 and 14 years at the date of the study. Gall stone prevalence was determined by real time ultrasound in a cross sectional study with informed consent in every case. Details of the number of children with each genotype, the total examined, and the prevalence of gall stones are given in the table. The mean serum total bilirubin concentration for each genotype was calculated from steady state values obtained at each child's birthday after four years; this is because of the rapid change in haematological indices before this age. ${ }^{3}$
Table Details of children studied

\begin{tabular}{|c|c|c|c|c|}
\hline Genotype & $\begin{array}{l}\text { No of } \\
\text { children in } \\
\text { cohort } \\
\text { study }\end{array}$ & $\begin{array}{l}\text { No of } \\
\text { children } \\
\text { screened }\end{array}$ & $\begin{array}{l}\text { No }(\%) \\
\text { with gall } \\
\text { stones }\end{array}$ & $\begin{array}{l}\text { Mean (range) } \\
\text { serum } \\
\text { bilirubin } \\
(\mu \mathrm{mol} / \mathrm{l})\end{array}$ \\
\hline $\begin{array}{l}\mathrm{SS} \\
\mathrm{SB}^{\circ} \\
\mathrm{SC} \\
\mathrm{SB}^{+}\end{array}$ & $\begin{array}{r}242 \\
11 \\
152 \\
33\end{array}$ & $\begin{array}{r}218 \\
9 \\
138 \\
25\end{array}$ & $\begin{aligned} & 30(14) \\
& 2(22) \\
& 4(3) \\
& 0\end{aligned}$ & $\begin{array}{l}35(27-38) \\
27(20-35) \\
19(16-22) \\
15(12-17)\end{array}$ \\
\hline
\end{tabular}

Gall stones were more common in homozygous sickle cell (SS) than sickle cell/haemoglobin C (SC) disease $\left(\chi^{2}=9 \cdot 7, p<0 \cdot 01\right)$, but other differences in prevalence were not significant. Gall stone prevalence was unreliably estimated in sickle cell/ $\beta$ (SB) thalassaemia due to small patient numbers. Mean serum bilirubin concentrations varied by genotype in a similar manner to gall stone prevalence, and data from the cohort study have shown differences by genotype in mean haemoglobin and reticulocyte count consistent with variation in haemolytic rate. ${ }^{4}$ Our data indicate that haemolysis, mean bilirubin, and gall stone prevalence vary by sickle genotype, and that the risk of gall stones is low in children with SC disease and $\mathrm{SB}^{+}$thalassaemia.

\section{References}

${ }^{1}$ Webb D K H, Darby J S, Dunn D T, Terry S I, Serjeant G R. ̊ Gall stones in homozygous sickle cell disease. Arch Dis Child 1989;64:693-6.

2 Rennals M B, Dunne M G, Grossman N J, Schwartz A D. Cholelithiasis in patients with major sickle hemoglobinopathies. Am J Dis Child 1984;138:66-7.

${ }^{3}$ Serjeant G R, Grandison Y, Lowrie Y, Phillips J, Serjeant B E, Vaidya $S$. The development of haematological changes in homozygous sickle cell disease: a cohort study from birth to 6 years. Br J Haematol 1981;48:533-43.

4 Stevens M C G, Maude G H, Beckford M, et al. Haematological change in sickle cell-haemoglobin $\mathrm{C}$ disease and sickle cell-beta thalassaemia: a cohort study from birth. Br J Haematol 1985;60:279-92.

D K Webb, D T Dunn, and G R Serjeant Medical Research Council Laboratories, University of the West Indies, Kingston 7, Jamaica

\section{Haemophilus influenzae type $b$ disease in the Oxford region}

Sir,

Tudor-Williams et al report an incidence of systemic Haemophilus influenzae type b disease in children less than 5 years of age of 33.4/100 000. ${ }^{1}$ This was determined from a detailed laboratory based study in the Oxford region and they urge others to set up similar prospective studies.

I have examined Hospital Activity Analysis (HAA) data for all deaths and discharges for $H$ influenzae meningitis (ICD Code 320.0) and acute epiglottitis (ICD Code 464.3) in the South Western region from 1976-86 and 1979-86 respectively. These two groups accounted for $80 \%$ of all 